Jurnal Ilmiah "Kreatif" Vol. XII No. 1 Januari 2015

"Jurnal Studi Pemikiran Pendidikan Agama Islam"

\title{
KAJIAN MENGENAI SUMBER DAYA MANUSIA DALAM PENDIDIKAN ISLAM
}

\author{
Oleh: $\mathcal{N}$ ursyamsiah ${ }^{\star}$
}

\begin{abstract}
Abstrak
Al-Qur'an mendudukan manusia sebagai makhluk ciptaan Allah berupa jasmani dan rohani. Al-Qur'an memberi acuan konseptual yang sangat mapan dalam memberi pemenuhan kebutuhan jasmani dan rohani agar manusia berkembang secara wajar dan baik. Al-Qur'an memberi keterangan tentang manusia dari berbagai segi, salah satunya untuk menjawab pertanyaan siapakan manusia itu? Dari ayat-ayat al-Qur'an tersebut, dapat disimpulkan bahwa manusia adalah makhluk fungsional yang bertanggungjawab. Sumber daya manusia merupakan bagian dari pelaksanaan pendidikan, yang dari semula telah mengarahkan manusia untuk berupaya meningkatkan kualitas hidupnya yang dimulai dari pengembangan budaya kecerdasan. Ini berarti bahwa titik tolaknya adalah pendidikan yang akan mempersiapkan manusia itu menjadi makhluk individual yang bertanggung jawab dan makhluk sosial yang mempunyai rasa kebersamaan dalam mewujudkan kehidupan yang damai, tentram, tertib, dan maju, dimana moral kebaikan (kebenaran, keadilan, dan kasih sayang) dapat ditegakkan sehingga kesejahteraan lahir batin dapat merata dinikmati bersama.
\end{abstract}

Kata Kunci: Ayat Al-Quran, Manusia, Fungsional, Pendidikan.

\section{Pendahuluan}

Manusia merupakan makhluk Tuhan yang kompleks dan unik serta diciptakan dalam integrasi dua substansi yang tidak berdiri sendiri yaitu tubuh (fisik atau jasmani) sebagai unsur materi, dan jiwa yang bersifat non materi. Hubungan kerja yang paling intensif dilingkungan organisasi adalah antara pemimpin dengan para pekerja (staf) yang menjadi bawahannya. Hubungan kerja semakin penting artinya; dalam usaha organisasi mewujudkan eksistensinya dilingkungan tugas yang lebih luas dan kompetetif pada masa yang akan datang.

Tantangan utama dalam mengelola sumber daya manusia adalah mengelola dengan efektif dan menghilangkan praktik-praktik yang tidak efektif. Dalam kondisi seperti itu, pimpinan dituntut selalu

*Penulis adalah Dosen STIT Sunan Giri Bima. Email: nursyamsiah_nata08@yahoo.co.id 
Jurnal Ilmiah "Kreatif" Vol. XII No. 1 Januari 2015

"Jurnal Studi Pemikiran Pendidikan Agama Islam"

mengembangkan cara-cara baru untuk dapat menarik dan mempertahankan para pejabat dan staf berkualitas yang diperlukan instansi agar tetap mampu bersaing.

Dalam hal pengembangan SDM, pendidikan memiliki nilai strategis dan mempunyai peran penting sebagai suatu investasi di masa depan. Karena secara teoritis, pendidikan adalah dasar dari pertumbuhan ekonomi, perkembangan sains dan teknologi, mengurangi kemiskinan dan ketimpangan dalam pendapatan dan peningkatan kualitas peradaban manusia pada umumnya. ${ }^{1}$ Nilai strategis pendidikan yang makro ini, menyimpulkan bahwa pendidikan menyimpan kekuatan luar biasa untuk menciptakan keseluruhan aspek lingkungan hidup dan dapat memberikan informasi paling berharga mengenai pegangan hidup di masa depan serta membantu anak didik mempersiapkan kebutuhan hidup yang esensial untuk menghadapi perubahan.

Dalam tulisan ini, penulis akan menjelaskan atau mendeskripsikan tentang hal apa saja yang berkaitan dengan sumber daya manusia, baik itu ditinjau dari segi al-Qur'an ataupun pendidikan Islam. Bagaimana konsep sumber daya manusia dan konsep pendidikan Islam? Apa Ayat-ayat al-Qur'an mengenai sumber daya manusia dalam Pendidikan Islam? Bagaimana kualitas sumber daya manusia yang Ideal dalam Pendidikan Islam (al-Qur'an)?

\section{Konsep Sumber Daya Manusia dan Pendidikan Islam}

Sumber daya manusia (selanjutnya akan disingkat SDM) merupakan suatu potensi yang terkandung dalam diri manusia untuk mewujudkan perannya sebagai makhluk sosial yang adaptif dan transformatif yang mampu mengelola dirinya sendiri serta seluruh potensi yang terkandung di alam menuju tercapainya kesejahteraan kehidupan dalam tatanan yang seimbang dan berkelanjutan. Dalam pengertian praktis sehari-hari, SDM lebih dimengerti sebagai bagian integral dari sistem yang membentuk suatu organisasi. Oleh karena itu, dalam bidang kajian psikologi, para praktisi SDM harus mengambil kosentrasi di bidang industri dan organisasi.

Dewasa ini, perkembangan SDM bukan sebagai sumber daya belaka, melainkan lebih berupa modal atau aset bagi institusi atau organisasi, karena itu kemudian muncullah istilah baru di luar H.R. (Human Resources). Di sini SDM dilihat bukan sekedar sebagai aset utama, tetapi aset yang bernilai dan dapat dilipatgandakan.

1 John Vaizey. Pendidikan di Dunia Modern. (Jakarta: Gunung Agung, 1980), 41 
Jurnal Ilmiah "Kreatif" Vol. XII No. 1 Januari 2015 "Jurnal Studi Pemikiran Pendidikan Agama Islam"

Terbentuknya pribadi seseorang dipengaruhi oleh lingkungannya bahkan secara extrime dapat dikatakan setiap orang berasal dari suatu lingkungan, baik lingkungan vertikal (genetika, tradisi) maupun lingkungan horizontal (geografik, fisik dan sosial), serta lingkungan kesejarahan. ${ }^{2}$

Pendidikan Islam merupakan sebuah rangkaian proses pemberdayaan manusia menuju kedewasaan, baik secara akal, mental, maupun moral untuk menjalankan fungsi kemanusiaan yang diemban sebagai seorang hamba di hadapan Khaliq-Nya dan sebagai "pemelihara" khalifah di alam semesta. Dengan demikian, fungsi utama pendidikan adalah mempersiapkan peserta didik (generasi penerus) dengan kemampuan dan keahlian yang diperlukan agar memiliki kemampuan dan kesiapan untuk terjun ke tengah masyarakat (lingkungan) sebagai tujuan akhir dari pendidikan.

Aktifitas pendidikan Islam pada dasarnya merupakan upaya dalam mewujudkan spirit Islami, yaitu suatu upaya dalam merealisasikan semangat hidup yang dijiwai oleh nilai Islami. Selanjutnya spirit tersebut digunakan sebagai pedoman hidup. Spirit Islami ini berakar dalam teksteks suci al-Qur'an yang disampaikan Allah kepada Nabi Muhammad Saw. Sebagai kitab suci agama Islam, a1-Qur'an mengintroduksikan dirinya sebagai "pemberi petunjuk kepada jalan yang lurus" (QS. al-Isra: 19) yaitu:

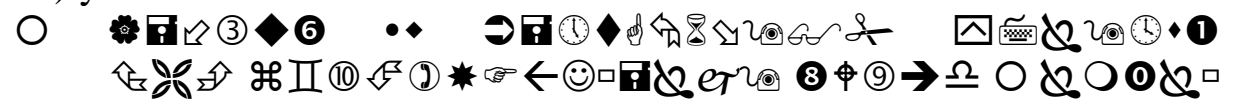

Artinya: Kitab (al-Quran) ini tidak ada keraguan padanya; petunjuk bagi mereka yang bertaqwa.

Petunjuk-petunjuknya bertujuan memberikan kesejahteraan dan kebahagiaan bagi manusia baik secara pribadi maupun kelompok, dan karena itu ditemukan petunjuk-petunjuk bagi manusia dalam kedua bentuk tersebut. Rasul sebagai penerima al-Qur'an bertugus untuk menyampaikan petunjuk-petunjuk tersebut, menyucikan dan mengajarkannya kepada manusia. Menyucikan dapat diidentikkan dengan mendidik (menjadikan seseorang bersih atau suci), sedangkan mengajar tidak lain untuk mengisi jiwa anak didik dengan pengetahuan yang berkaitan dengan alam fisik dan metafisik.

Tujuan akhir pendidikan Islam, sebagai proses pembentukan diri peserta didik manusia agar sesuai dengan fitrah keberadaannya. Hal ini meniscayakan adanya kebebasan gerak bagi setiap elemen dalam

2 Taliziduhu Ndarha. Pengantar Teori Pengembangan Sumber Daya Manusia. (Jakarta: PT Rienika Cipta, 1999), 7-8 
Jurnal Ilmiah "Kreatif" Vol. XII No. 1 Januari 2015

"Jurnal Studi Pemikiran Pendidikan Agama Islam"

dunia pendidikan terutama peserta didik untuk mengembangkan diri dan potensi yang dimilikinya secara maksimal. Pada masa kejayaan Islam, pendidikan telah mampu menjalankan perannya sebagai wadah pemberdayaan peserta didik, namun seiring dengan kemunduran dunia Islam, dunia pendidikan Islam pun turut mengalami kemunduran. Bahkan dalam paradigma pun terjadi pergeseran dari paradigma aktifprogresif menjadi pasif-defensif. Akibatnya, pendidikan Islam mengalami proses "isolasi diri" dan termarginalkan dari lingkungan di mana ia berada. ${ }^{3}$

Manusia diciptakan oleh Allah sebagai penerima dan pelaksana ajaran sehingga ia ditempatkan pada kedudukan yang mulia. Untuk mempertahankan kedudukannya yang mulia dan bentuk pribadi yang bagus itu, Allah melengkapinya dengan akal dan perasaan yang memungkinkannya menerima dan mengembangkan ilmu pengetahuan dan membudayakan ilmu yang dimilikinya. ini berarti bahwa kedudukan manusia sebagai makhluk yang mulia itu karena akal dan perasaan, ilmu pengetahuan dan kebudayaan yang seluruhnya dikaitkan kepada pengabdian pada pencipta. ${ }^{4}$

Potensi-potensi yang diberikan kepada manusia pada dasarnya merupakan petunjuk Allah yang diperuntukkan bagi manusia supaya ia dapat mewujudkan sikap hidup yang serasi dengan hakekat penciptaannya. Sejalan dengan upaya pembinaan seluruh potensi manusia, Muhammad Quthb berpendapat bahwa Islam melakukan pendidikan dengan melakukan pendekatan yang menyeluruh terhadap wujud manusia, sehingga tidak ada yang tertinggal dan terabaikan sedikitpun, baik dari segi jasmani maupun segi rohani, baik kehidupannya secara mental, dan segala kegiatannya di bumi ini. Islam memandang manusia secara totalitas, mendekatinya atas dasar apa yang terdapat dalam dirinya, atas dasar fitrah yang diberikan Allah kepadanya, tidak ada sedikitpun yang diabaikan dan tidak memaksakan apapun selain apa yang dijadikannya sesuai dengan fitrahnya. Pendapat ini memberikan petunjuk dengan jelas bahwa dalam rangka mencapai pendidikan Islam harus diupayakan pembinaan seluruh potensi secara serasi dan seimbang. ${ }^{5}$

\section{Ayat-ayat al-Qur'an Mengenai SDM dalam Pendidikan Islam}

${ }^{3}$ Ahmad S. Adnan Purta. Strategi Pengembangan SDM Menurut Konsep Islam. Dalam Majalah Triwulan Mimbar Ilmiah. Universitas Djakarta. Januari 1994, 52

${ }^{4}$ Zakiah Darajad. Ilmu Pendidikan Islam. (Jakarta: Bumi Aksara, 1996), 3

5 Wakhudin, Tarmizi Taher. Jembatan Umat, Ulama dan Umara. (Bandung: Granesia, 1998), 240-241 
Jurnal Ilmiah "Kreatif" Vol. XII No. 1 Januari 2015

"Jurnal Studi Pemikiran Pendidikan Agama Islam"

Menurut Moh. Kasiram sebagaimana yang dikutip oleh Asmaun Sahlan, bahwa kualitas sumber daya manusia ini menyangkut dua aspek, yaitu aspek fisik (kualitas fisik) dan aspek non-fisik (kualitas non-fisik) yang menyangkut kemampuan bekerja, berpikir, dan keterampilan-keterampilan lain. Oleh sebab itu, upaya meningkatkan kualitas sumber daya manusia ini diarahkan kepada dua aspek tersebut. Untuk meningkatkan kualitas fisik, dapat diusahakan melalui programprogram kesehatan gizi. Sedangkan untuk meningkatkan kualitas dan kemampuan-kemampuan non-fisik tersebut, maka upaya pendidikan dan pelatihan adalah penting diperlukan. Upaya inilah yang dimaksud dengan pengembangan sumber daya manusia. ${ }^{6}$

Sedang konsep pengembangan SDM dalam Islam banyak sekali ditunjukkan oleh ayat-ayat al-Quran. Dari sejumlah ayat yang ada, menjelaskan bahwa SDM yang berkualitas menurut Islam adalah individu yang mampu mencapai derajat Ulul Albab seperti yang dijelaskan dalam surat Al-Imran ayat 191.

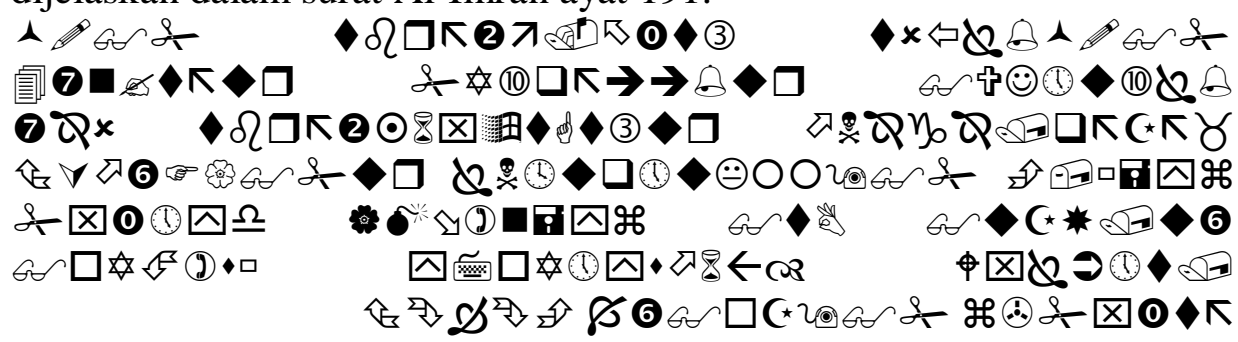

Artinya: "(yaitu) orang-orang yang mengingat Allah sambil berdiri atau duduk atau dalam keadan berbaring dan mereka memikirkan tentang penciptaan langit dan bumi (seraya berkata): "Ya Tuhan kami, tiadalah Engkau menciptakan ini dengan sia-sia, Maha suci Engkau, maka peliharalah kami dari siksa neraka."

Keunggulan Ulul Albab adalah sosok pribadi yang sudah mampu berdaya guna dan berhasil guna dalam tiga aktifitas, yaitu: dzikir, fikir dan fi 'il (berkarya). Kemampuan dzikir Ulul Albab memberi arti bahwa mereka selalu sadar sebagai hamba Allah. Dzikir yang dimaksud adalah dzikir pasif yaitu berdzikir kepada Allah seperti biasa dilakukan dalam beribadah maupun dzikir aktif yaitu berpikir mendalam tentang alam dan isinya.

Kemampuan berpikir Ulul Albab adalah berpikir tentang penciptaan langit dan bumi, tidak identik dengan melamun, menghayal atau sekedar berpikir kosong. Namun, ini diartikan dalam tindakan nyata yang mencakup praktek penelitian dan eksperimen untuk mengetahui

Malang, 2004), 3

${ }^{6}$ Asmaun Sahlan. Pendidikan dan kualitas SDM. (Malang: Tarbiyah UIN 
Jurnal Ilmiah "Kreatif" Vol. XII No. 1 Januari 2015

"Jurnal Studi Pemikiran Pendidikan Agama Islam"

kebesaran Allah, yang berarti untuk melakukan kemajuan-kemajuan dalam bidang sains dan teknologi.

Kemampuan $f i$ 'il atau beramal sholeh Ulul Albab sedikitnya merangkum tiga dimensi. Pertama, profesionalisme; kedua, transenden berupa pengabdian dan keikhlasan; ketiga, kemaslahatan bagi kehidupan pada umumnya pekerjaan yang dilakukan oleh Ulul Albab didasarkan pada keahlian dan rasa tanggung jawab tinggi. Apalagi amal sholeh selalu terkait dengan dimensi keutamaan dan transenden, maka mereka melakukannya dengan kualitas tinggi. ${ }^{7}$ Firman Allah dalam Al-Qur'an surat at-Tiin ayat 4:

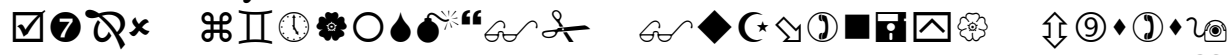

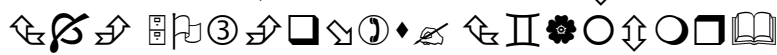

Artinya: "Sesungguhnya Kami telah menciptakan manusia dalam bentuk yang sebaik-baiknya."

Hal ini juga dipertegas dalam hadis Nabi Muhammad Saw:

$$
\text { إنما بعثت لأتمم مكارم الأخلا ق }
$$

Artinya: Sesungguhnya aku diutus ke dunia untuk menyempurnakan akhlak dan budi pekerti. (HR. Ahmad, Baihaqi dan Hakim).

Ayat Al-Qur'an dan hadits di atas memberikan gambaran bahwa makhluk manusia merupakan makhluk yang sebaik-baiknya, sempurna dan berkecenderungan untuk berakhlak karimah. Hal ini dapat dilihat dari aspek kognitif, afektif dan psikomotoriknya. Sebagaimana dinyatakan oleh Nanih Machendrawati, bahwa aspek kognitif dan afektif (ahsani taqwiim) ini akan membangun atau membentuk aspek psikomotorik, yakni amal saleh atau kemampuan berpikir, merasa, bersikap dan berbuat baik. ${ }^{8}$

Dalam pendidikan Islam khususnya dimensi yang hendak dituju dan ditingkatkan oleh kegiatan pendidikan Islam, yaitu:

1. Dimensi keimanan peserta didik terhadap ajaran agama Islam.

2. Dimensi pemahaman dan penalaran (intelektual) serta keilmuan peserta didik terhadap ajaran agama Islam.

3. Dimensi penghayatan dan pengamalan batin yang dirasakan peserta didik dalam menjalankan ajaran agama Islam.

4. Dimensi pengamalannya, dalam artian bagaimana ajaran Islam yang telah diimani, dipahami dan dihayati oleh peserta didik itu mampu diamalkan dalam kehidupan pribadi sebagai manusia yang beriman

${ }^{7}$ STAIN Malang. Tarbiyah Uli Al-Albab: Dzikir, Fikr, dan Amal Shalih. (Malang: STAIN Malang, 2002), 9

8 Nanih Machendrawati. Pengembangan Masyarakat Islam. (Bandung: Remaja Rosda Karya, 2002), 163 
Jurnal Ilmiah "Kreatif" Vol. XII No. 1 Januari 2015

"Jurnal Studi Pemikiran Pendidikan Agama Islam"

dan bertaqwa kepada Allah Swt, berakhlak mulia serta diaktualisasikan dalam kehidupan bermasyarakat, berbangsa dan bernegara. ${ }^{9}$

Dari berbagai dimensi yang dipaparkan diatas, penulis dapat menyimpulkan bahwa aspek kognitif (ilmu pengetahuan), afektif (sikap), dan psikomotorik (ketrampilan) sangat mempengaruhi dalam proses pembentukan kepribadian SDM. Oleh karena itu perlu adanya keseimbangan antara ranah tersebut dengan nilai-nilai ajaran agama Islam.

\section{Kualitas Sumber Daya Manusia yang Ideal dalam Pendidikan Islam (al-Qur'an)}

Menurut H. A. R.Tilaar dapat ditemukan ciri-ciri manusia yang berkualitas yaitu: (a) Manusia yang beriman dan bertaqwa kepada Tuhan yang maha esa; (b) Berbudi luhur; (c) Berkepribadian; (d) Berdisiplin; (e) Bekerja keras; (f) Tangguh; (g) Bertanggungjawab; (h) Mandiri; (i) Cerdas dan terampil; (j) Sehat jasmani dan rohani; (k) Cinta tanah air; (l) Semangat kebangsaan yang tinggi; (m) Mempunyai rasa kesetiakawanan sosial; (n) Sikap inovatif dan kreatif: ${ }^{10}$

Sedangkan menurut Syahminan Zaini menjelaskan syaratsyarat untuk mencapai kehidupan yang makmur, sejahtera di dunia dan akhirat, terdapat beberapa ciri yang harus dimiliki oleh manusia yang berkualitas:

1. Mempunyai pendirian yang teguh (istiqomah).

Kualitas sumber daya manusia juga dituntut untuk memiliki pendirian yang teguh terhadap segala ucapan dan perbuatannya, agar tidak mudah terjerumus ke dalam hal-hal yang bisa mencelakakan dirinya.

Dalam surat Hud ayat 112:

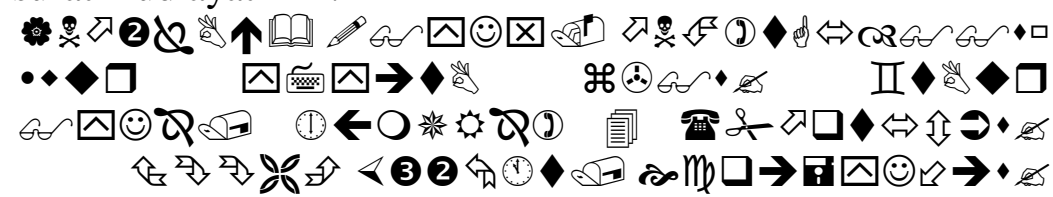

Artinya: "Maka tetaplah kamu pada jalan yang benar, sebagaimana diperintahkan kepadamu dan (juga) orang yang telah taubat beserta kamu dan janganlah kamu melampaui batas. Sesungguhnya Dia Maha melihat apa yang kamu kerjakan.”

9 Muhaimin dkk. Strategi Belajar Mengajar Penerapannya dalam Pembelajaran Agama Islam. (Surabaya: Media Karya Anak Bangsa, 1996), 2

${ }^{10}$ H.A.R. Tilaar. Pendidikan dalam Pembangunan Nasional Menyongsong Abad XXI. (Jakarta: Balai Pustaka, 1990), 116 
Jurnal Ilmiah "Kreatif" Vol. XII No. 1 Januari 2015

"Jurnal Studi Pemikiriran Pendidikan Agama Islam"

Kalau pendirian sudah teguh, maka diajarkan pula untuk mempertanggungjawabkannya, yaitu kalau ucapan dan perbuatan itu baik, maka dia harus mempertahankan dan meningkatkannya agar tetap baik dan benar, akan tetapi kalau jelek harus diperbaiki.

2. Mempunyai jasmani sehat dan kuat.

Kualitas sumber daya manusia yang ideal itu adalah harus memiliki jasmani yang sehat dan kuat, sehingga mampu melaksanakan aktivitas hidupnya dengan baik, sebab jika seseorang mempunyai badan dan jiwa yang lemah maka tidak mampu menjalankan aktifitas dengan baik. Oleh karena itu, Islam menganjurkan agar segala sumber daya yang dimiliki oleh jasmani itu harus sehat dan kuat. Sebagaimana pepatah mengatakan: "Al'Aqlu as-saliim fil jismi as-salim". Jika badan seseorang sehat, maka jiwa pun sehat.

3. Mempunyai jasmani yang terampil dan profesional.

Dengan adanya jasmani yang sehat dan kuat tersebut, kualitas sumber daya manusia yang diharapkan memiliki ketrampilan yang memadai, agar sumber daya jasmani yang memadai tadi bisa bermanfaat bagi kehidupannya. Dalam Islam dianjurkan agar sumber daya jasmaninya itu dipergunakan dengan sebaik-baiknya, dengan ketrampilan yang memadai.

4. Mempunyai akal yang cerdas dan ilmu pengetahuan yang banyak.

Intelektualitas yang cerdas yang dimaksud disini adalah akal yang memiliki atau menguasai ilmu pengetahuan dan teknologi (IPTEK) yang kreatif sehingga ketrampilan yang dimilikinya itu bisa bermanfaat dengan baik yaitu dengan mengetahui cara (metode) menggunakan keterampilan itu, Islam pun menganjurkan agar daya intelek yang dimiliki manusia harus menguasai dan memiliki IPTEK. Dalam ayat al-Qur'an antara lain dijelaskan dalam surat al-Imran ayat 190-191, menjelaskan tentang manusia diperintahkan untuk menggunakan sumber daya intelektualnya dengan kegiatan berdzikir dan berfikir tentang segala ciptaan Allah di alam ini, sehingga manusia mampu memperolah kesimpulan bahwa alam semesta ini bermanfaat, tidak ada yang tidak berguna.

5. Mempunyai semangat kerja yang tinggi dan bersungguh-sungguh.

Dengan adanya ketrampilan dan IPTEK yang dimilikinya, maka dia diharuskan untuk merealisasikannya ke dalam kehidupannya. Dalam artian, harus mengerjakan perbuatannya dengan sebaikbaiknya dan sungguh-sungguh serta dikerjakan secara professional sehingga bermanfaat bagi dirinya, keluarga, masyarakat, maupun negaranya. 
Jurnal ITmiah "Kreatif" Vol. XII No. 1 Januari 2015

"Jurnal Studi Pemikiran Pendidikan Agama Islam"

Dalam al-Qur'an disebutkan pada surat al-Hajj ayat 78, yang berbunyi:

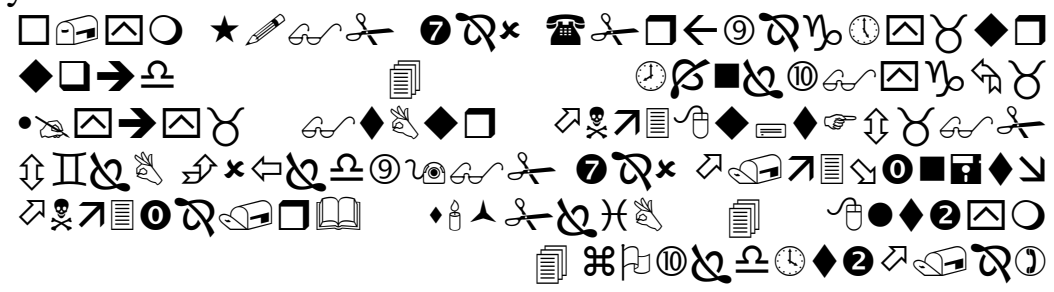

Artinya: "Dan berjihadlah kamu pada jalan Allah dengan Jihad yang sebenar-benarnya. Dia telah memilih kamu dan Dia sekali-kali tidak menjadikan untuk kamu dalam agama suatu kesempitan. (Ikutilah) agama orang tuamu Ibrahim."

6. Mempunyai disiplin yang tinggi serta akhlak yang mulia.

Dalam pelaksanaan perbuatan itu, dia harus bekerja sesuai dengan norma-norma atau nilai-nilai moral yang tinggi, agar pekerjaan itu bisa berhasil sesuai dengan yang diharapkan. Oleh karena itu kualitas sumber daya manusia dituntut untuk mempunyai akhlak yang mulia dan disiplin yang tinggi. Dalam Islampun dianjurkan agar manusia dalam melaksanakan pekerjaan itu harus dengan cara yang baik. Dalam arti harus memiliki nilai moral dan akhlak karena segala sesuatu yang ada didunia ini diatur oleh sebuah aturan yang telah disepakati bersama. Jika hal ini tidak diperhatikan akan terjadi pelanggaran nilai-nilai agama yang dapat mengancam kehidupan masyarakat, bangsa, dan negara bahkan dirinya sendiri. ${ }^{11}$

7. Mempunyai hati yang tunduk kepada Allah dan rasul-Nya.

Kualitas sumber daya manusia yang ideal adalah yang beriman dan bertaqwa kepada Allah dengan benar dan sungguh-sungguh melalui hati yang tunduk, patuh, dan taat menjalankan agamanya dengan amal ibadah kepada Tuhannya, baik amal ibadah yang bersifat duniawi seperti bekerja keras untuk memenuhi hidupnya, membangun bangsa dan negaranya. Maupun amal yang bersifat ukhrawi seperti sholat, zakat, puasa, dan haji. Taqwa juga memelihara diri yaitu memelihara diri dari amarah dan murka Allah dengan menjalankan perintah-Nya. Dengan demikian semua ciri ideal kualitas sumber daya manusia yang disebutkan di atas, semuanya mencakup keimanan dan ketaqwaan ini, sebab dalam Islam ciri yang terakhir ini merupakan ciri yang paling menentukan berkualitas atau tidaknya sumber daya manusia. Keimanan dan ketaqwaaan inilah yang mengantarkan segala usaha manusia berhasil

11 Syahminan Zaini. Prinsip-prinsip Dasar Konsepsi Pendidikan Islam. (Jakarta: Kalam Mulia, 1986), 48 
Jurnal Ilmiah "Kreatif" Vol. XII No. 1 Januari 2015

"Jurnal Studi Pemikiran Pendidikan Agama Islam"

dengan baik, di dunia maupun di akhirat. Sebagaimana firman Allah dalam surat al-'Araf ayat 96, yang berbunyi:

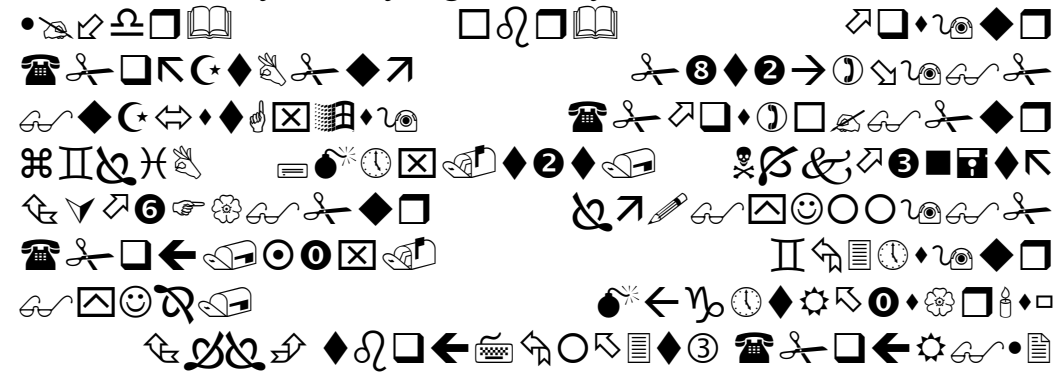

Artinya: "Jikalau sekiranya penduduk negeri-negeri beriman dan bertakwa, pastilah Kami akan melimpahkan kepada mereka berkah dari langit dan bumi, tetapi mereka mendustakan (ayat-ayat Kami) itu, Maka Kami siksa mereka disebabkan perbuatannya."

Ayat diatas menjelaskan kualitas sumber daya manusia yang memiliki keimanan dan ketaqwaan itu akan mendapatkan keuntungan di dunia dan akhirat. Dari sini jelas bahwa keimanan dan ketaqwaan merupakan ciri ideal kualitas sumber daya manusia yang sangat menentukan keberhasilan bagi segala aktifitas manusia, baik yang bersifat duniawi maupun yang bersifat ukhrawi. ${ }^{12}$

Kualitas SDM tidak akan sempurna tanpa ketangguhan mental-spiritual keagamaan. Sebab, penguasaan IPTEK belaka bukan merupakan salah satu jaminan bagi kesejahteraan manusia secara keseluruhan. Sumber daya manusia yang memegang nilai-nilai agama akan lebih tangguh secara rohaniah. Dengan demikian akan lebih mempunyai rasa tanggung jawab spiritual terhadap IPTEK.

IPTEK yang telah diraih oleh manusia dalam pandangan Islam harus dapat mencapai kebahagiaan material dan spiritual umat manusia bagi tercapainya suatu kehidupan yang dikenal dengan sebutan rahmatan lil alamin. Dengan persepsi kepercayaan kepada Allah yang Maha Esa sebagai nilai dasar dalam pengembangan sumber daya bagi manusia, maka akan terdapat dalam masyarakat suatu kehidupan yang jujur, rukun, manusiawi, adil, dan beradab sejalan dengan kehendak Ilahi yang menjunjung tinggi harkat dan martabat manusia yang diciptakan dengan dilengkapi daya kekuatan yang dikenal dengan istilah human resources. ${ }^{13}$

${ }^{12}$ Harun Nasution. Islam Rasional, Gagasan dan Pemikiran. (Bandung: Mizan), 409

${ }^{13}$ Ibid, 240 
Jurnal Ilmiah "Kreatif" Vol. XII No. 1 Januari 2015

"Jurnal Studi Pemikiran Pendidikan Agama Islam"

\section{Simpulan}

Pada zaman sekarang, SDM yang berkualitas sangat diperlukan dalam berbagai bidang. SDM sangat menentukan dalam mencapai keberhasilan. Aspek kognitif, afektif, dan psikomotorik sangat memengaruhi dalam proses pembentukan kepribadian SDM. Jadi harus ada keseimbangan antara yang satu dengan yang lainnya, dan juga semua ranah tersebut tidak akan berfungsi dengan baik kalau tidak dibarengi dengan nilai-nilai ajaran agama Islam.

Dalam artian lain bahwa manusia atau SDM harus bisa mengembangkan dirinya sehingga dia menjadi SDM yang berkualitas, kriteria manusia ideal yang berkualitas adalah manusia yang beriman dan bertakwa, kreatif, inovatif, produktif, mandiri berdisiplin, profesional serta memiliki motivasi kerja yang tinggi.

Manusia sebagai khalifah di muka bumi berkewajiban untuk menjaga kemakmuran dan mencegah kehancurannya. Dalam hal ini menciptakan sumber daya manusia yang berkualitas dan mampu berprestasi untuk mengelola bumi seisinya, bahkan luar angkasa atau planet luar bumi yang kita diami ini.

Pendidikan Islam harus dapat mengembangkan kemampuan dan tingkah laku manusia yang dapat menjawab tantangan internal maupun tantangan global menuju masyarakat yang demokratis, berkualitas, dan kritis. Pendidikan harus dikembangkan berdasarkan tuntutan acuan perubahan tersebut dan berdasarkan karakteristik masyarakat yang demokratls, berkualitas dan kritis. Sedangkan untuk menghadapi kehidupan global, proses pendidikan Islam yang diperlukan adalah mampu mengembangkan kemampuan berkompetisi, kemampuan kerja sama, mengembangkan sikap inovatif, serta meningkatkan kualitas.

Kualitas sumber daya manusia yang memiliki keimanan dan ketakwaan itu akan mendapatkan keuntungan di dunia dan akhirat. Dari sini jelas bahwa keimanan dan ketakwaan merupakan ciri ideal kualitas sumber daya manusia yang sangat menentukan keberhasilan bagi segala aktifitas manusia, baik yang bersifat duniawi maupun ukhrawi.

Kualitas SDM tidak akan sempurna tanpa ketangguhan mental-spiritual keagamaan. Sebab, penguasaan IPTEK belaka tidaklah merupakan salah satunya jaminan bagi kesejahteraan manusia secara keseluruhan. Sumber daya manusia yang memegang nilai-nilai agama akan lebih tangguh secara rohaniah. Dengan demikian akan lebih mempunyai rasa tanggung jawab spiritual terhadap IPTEK. 
Jurnal Ilmiah "Kreatif" Vol. XII No. 1 Januari 2015

"Iurnal Studi Pemikiran Pendidikan Agama Islam"

\section{Daftar Pustaka}

Adnan Purta, Ahmad S. Strategi Pengembangan SDM Menurut Konsep Islam. Dalam Majalah Triwulan Mimbar Ilmiah. Universitas Djakarta. Januari 1994

Darajad, Zakiah. Ilmu Pendidikan Islam. Jakarta: Bumi Aksara, 1996.

Langgulung, Hasan. Beberapa pemikir Tentang Pendidikan Islam, Bandung: Al Ma'arif, 1995.

Machendrawati, Nanih. Pengembangan Masyarakat Islam, Bandung: Remaja Rosda Karya, 2002.

Muhaimin dkk. Strategi Belajar Mengajar Penerapannya dalam Pembelajaran Agama Islam, Surabaya: Media Karya Anak Bangsa, 1996.

Nasution, Harun. Islam Rasional, Gagasan dan Pemikiran, Bandung: Mizan,

Ndarha, Taliziduhu. Pengantar Teori Pengembangan Sumber Daya Manusia, Jakarta: Rhineka Cipta, 1999.

Sahlan, Asmaun. Pendidikan dan kualitas SDM, Malang: Tarbiyah UIN Malang, 2004.

STAIN Malang. Tarbiyah Uli Al-Albab: Dzikir, Fikr, dan Amal Shalih, Malang: STAIN Malang, 2002.

Tilaar, H.A.R. Pendidikan dalam Pembangunan Nasional Menyongsong Abad XXI, Jakarta: Balai Pustaka, 1990.

Vaizey, John. Pendidikan di Dunia Modern, Jakarta: Gunung Agung, 1980.

Wakhudin, Tarmizi Taher. Jembatan Umat, Ulama dan Umara, Bandung: Granesia, 1998.

Zaini, Syahminan. Prinsip-prinsip Dasar Konsepsi Pendidikan Islam, Jakarta: Kalam Mulia, 1986. 